\title{
Large Osteochondral Allografts of the Knee: Surgical Technique and Indications
}

\author{
Gabriele Pisanu ${ }^{1}$ Umberto Cottino ${ }^{1}$ Federica Rosso $^{1}$ Davide Blonna ${ }^{1}$ Antonio Giulio Marmotti ${ }^{1}$ \\ Corrado Bertolo $^{1}$ Roberto Rossi ${ }^{1}$ Davide E. Bonasia ${ }^{1}$ \\ ${ }^{1}$ Department of Orthopaedics and Traumatology, University of Study \\ of Turin, Turin, Italy \\ Address for correspondence Gabriele Pisanu, MD, Department of \\ Orthopaedics and Traumatology, University of Study of Turin, Ao \\ Joints 2018;6:42-53. \\ Mauriziano Umberto I, Largo Turati 62, Turin 10128, Italy \\ (e-mail: gabriele.pisanu@libero.it).
}

Abstract
Keywords
- knee
- chondral lesion
- osteochondral lesion
- allograft
- osteochondral
allograft

Large osteochondral allograft (OCA) transplant has become a valid alternative to restore articular surface in challenging articular lesions in young and active patients, either in primary or in revision procedures. Several studies support the effectiveness and safety of OCA, but costs and graft availability limit their use. The indications are the treatment of symptomatic full-thickness cartilage lesions greater than $3 \mathrm{~cm}^{2}$, deep lesions with subchondral damage, or revision procedures when a previous treatment has failed. The goal of the transplant is to restore the articular surface with a biological implant, allow return to daily/sports activities, relieve symptoms, and delay knee arthroplasty. Grafts can be fresh, fresh-frozen, or cryopreserved; these different storage procedures significantly affect cell viability, immunogenicity, and duration of the storage. Dowel and shell technique are the two most commonly used procedures for OCA transplantation. While most cartilage lesions can be treated with the dowel technique, large and/or geometrically irregular lesions should be treated with the shell technique. OCA transplantation for the knee has demonstrated reliable mid- to longterm results in terms of graft survival and patient satisfaction. Best results are reported: in unipolar lesions, in patients younger than 30 years, in traumatic lesions and when the treatment is performed within 12 months from the onset of symptoms.

\section{Introduction}

Articular cartilage lesions of the knee are common in active and young population. ${ }^{1}$ Curl et $\mathrm{al}^{2}$ reviewed more than 30,000 patients treated with knee arthroscopy, reporting chondral lesions in $63 \%$ of cases. Arøen et al, ${ }^{3}$ in a group of approximately a thousand patients undergoing knee arthroscopy with a mean age of 35 years, found a full-thickness cartilage lesion suitable for cartilage repair in $11 \%$ of cases. Several studies reported Outerbridge grade III and IV lesions in 5 to $20 \%$ of all patients undergoing knee arthroscopy, with 4 to $5 \%$ of these patients being younger than 40 years. ${ }^{2-4}$

Different techniques can be used to repair osteochondral lesions of the knee, and these can be categorized into four group: bone marrow stimulation procedures, osteochondral scaffold, cell therapies, and osteochondral grafting. Debride- ment and microfractures with bone marrow stimulation are suitable options for lesions smaller than $2 \mathrm{~cm}^{2}$ without subchondral bone damage. ${ }^{5-7}$ These procedures result in fibrocartilage repair tissue; this tissue has poor biomechanical properties compared with hyaline cartilage, degenerates faster, and is generally thinner. ${ }^{8-10}$ Autologous mosaicplasty has the potential to restore small osteochondral lesions but is not indicated in large lesions $\left(>2.5 \mathrm{~cm}^{2}\right)$ due to significant donor-site morbidity and the technical difficulties in restoring curved surfaces and uncontained defects. ${ }^{11-14}$ Autologous chondrocytes implantation provides surface coverage with hyaline-like repair tissue, but it is costly, entails two surgical procedures, and does not restore associated bone defects unless bone grafting is performed. ${ }^{15}$ Cell-free scaffolds and the use of growth factors are promising new technologies but require additional published online March 13, 2018
DOI https://doi.org/ $10.1055 / \mathrm{s}-0038-1636925$. ISSN 2282-4324.
Copyright (c) 2018 Georg Thieme Verlag License terms KG Stuttgart · New York 
studies to confirm the initial good results in small lesions with little damage to the subchondral bone. ${ }^{13}$ Stem cell therapy showed promising results, but currently, clinical and preclinical trials are trying to establish the optimal cell type to use, the safety, and the efficacy. ${ }^{16}$

Osteochondral allograft (OCA) represents a solution for the treatment of large and deep osteochondral lesions, in both primary and revision procedures, with different advantages: possibility of covering virtually all sizes of defects, presence of subchondral bone, possibility of restoring complex surfaces and uncontained lesions, and absence of donorsite morbidity. ${ }^{17-28}$ The main limitations of OCA are costs and graft availability. ${ }^{29}$

OCAs are most commonly used for femoral condyle defects, but they can also be used in tibial plateau and patellofemoral defects. The goals for OCA transplant are to restore the articular surface, return to daily/sports activities, relieve symptoms, and delay knee arthroplasty, ${ }^{18,20}$ considering that knee arthroplasty has shown inferior outcomes in young patients. ${ }^{30,31}$

\section{Indications}

OCA is indicated for the primary management of symptomatic full-thickness cartilage lesions greater than $3 \mathrm{~cm}^{2}$ or localized Outerbridge grade III or IV lesions with subchondral bone damage greater than 6 to $10 \mathrm{~mm} .^{5,19,32-35}$ OCA transplants have also proven to be a useful revision cartilage restoration procedure after microfractures, osteochondral autograft transplantation, or autologous chondrocyte implantation. ${ }^{8,36}$ OCA transplantation can be used in different scenarios such as osteonecrosis, osteochondritis dissecans (OCD), and degenerative or posttraumatic focal lesions. ${ }^{1,23-27,37}$ Extreme indications include hemicondylic and whole condylic grafting; these are suitable for young high-demanding patients with large posttraumatic lesions or bone reconstruction for tumor resections. ${ }^{1,20,23-27}$
Only a few studies on osteochondral tibial lesion management are available reporting transplant of the whole tibial plateau, and this should be considered only in case of large and deep lesions or failed prior surgery (i.e., fracture reduction fixation or failed cartilage procedure).$^{20}$ If a concomitant meniscal deficiency is present, a combined OCA transplant and meniscal allograft transplant (MAT) should be considered. ${ }^{38}$ Also, in patellofemoral lesions, OCAs have to be considered only in revision surgery after failed cell-based or cell-free techniques. ${ }^{20}$

OCA transplantation should only be considered as a primary approach in young patients when complete patellar or trochlear resurfacing is required. ${ }^{20}$

Absolute contraindications include early and multicompartmental osteoarthritis (OA), inflammatory arthropathies, and altered bone metabolism (i.e., smokers, alcohol abusers, and chronic steroid users). ${ }^{17}$

Bipolar OCAs are generally contraindicated because of the poor results described in the literature. ${ }^{39-41}$ Ligamentous instability, malalignment, and the absence of $>50 \%$ of the ipsilateral meniscus are relative contraindications that may require concomitant surgical procedures. ${ }^{17}$

Obese patients (body mass index $>30 \mathrm{~kg} / \mathrm{m}^{2}$ ) and lowdemand patients who meet the criteria for joint replacement should not be indicated for OCA. ${ }^{18}$

\section{Preoperative Planning}

A detailed clinical history, accurate examination, and imaging must be obtained. Preoperative radiographic views should be obtained with sizing markers to calculate the appropriate allograft size. They include long-leg standing anteroposterior view to assess the mechanical axis, Rosenberg view to assess the femorotibial joint line, and lateral, sunrise, or Merchant views to assess the patellofemoral joint (-Fig. 1). ${ }^{8}$ Alternatively, magnetic resonance imaging (MRI) can be used to determine the allograft size, ${ }^{32}$ although MRI

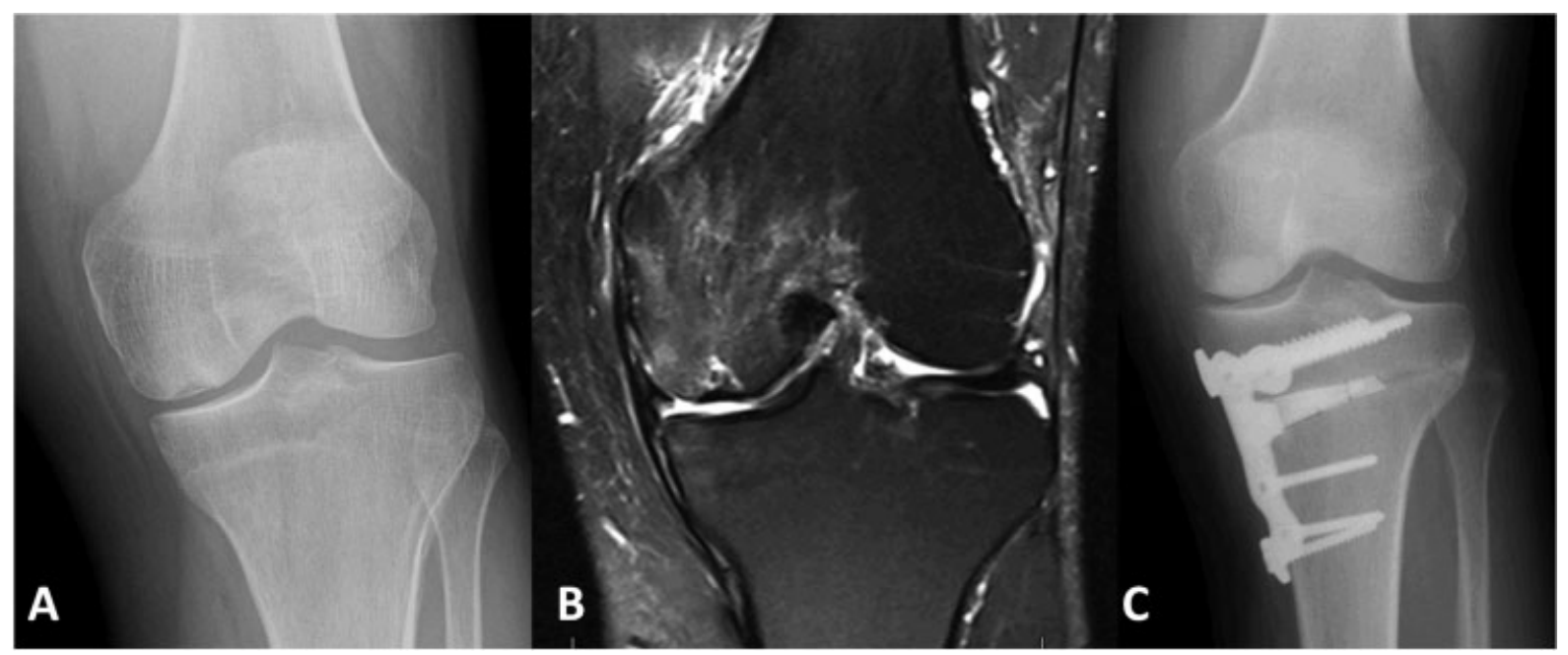

Fig. 1 (A) Anteroposterior X-ray view of a medial femoral condyle osteochondritis dissecans with varus malalignment. (B) Coronal magnetic resonance imaging (MRI) of the same case. (C) Postoperative anteroposterior X-ray view after opening-wedge high tibial osteotomy and medial femoral condyle osteochondral autograft transplantations. 
can underestimate the size of the lesion up to $60 \%{ }^{42,43}$ In addition, MRI is necessary to evaluate ligaments, menisci, and subchondral bone. ${ }^{20}$

Computed tomography (CT) scan is useful to evaluate the involvement of the bone around the defect or patellofemoral maltracking/instability. ${ }^{20}$

The imaging of the affected knee is sent to the tissue bank for correct sizing of the OCA. ${ }^{44}$

\section{Harvesting, Processing, and Storage}

The primary goal of the storage is to biologically preserve subchondral bone and keep viable chondrocytes after transplantation; ${ }^{18}$ this aspect is of paramount importance to achieve good results with OCA. ${ }^{45,46}$

Grafts can be fresh, fresh-frozen, and cryopreserved; these different storage procedures have different consequences on cell viability, immunogenicity, and duration of the storage itself.

A long storage time jeopardizes both biomechanical properties of the cartilage and viability of chondrocytes. ${ }^{47}$ In fresh OCA stored at $4^{\circ} \mathrm{C}$, chondrocyte viability starts to decrease from the third week of storage, and for this reason, the graft should be used within 28 days from harvesting (at this time point, $70 \%$ of chondrocytes are still alive and active). ${ }^{1,45,48}$

Cryopreserved OCAs are stored in a cryoprotectant storage medium of glycerol or dimethyl sulfoxide at $-70^{\circ} \mathrm{C}$ in a controlled procedure to protect cell viability, but this technique is controversial due to failure of the cryopreservant to penetrate the deeper zones of the graft. ${ }^{49,50}$

Fresh-frozen OCAs undergo deep freezing to $-80^{\circ} \mathrm{C}$ and have the advantage of potential long storage time and decreased immunogenicity; however, up to $95 \%$ of the chondrocytes are lost with this technique. ${ }^{1,51,52}$ The low portions of viable chondrocytes in both fresh-frozen and cryopreserved grafts have limited their use. ${ }^{53}$

Fresh OCAs are stored in either saline solution or Ringer's lactate medium at $4^{\circ} \mathrm{C}$. Graft storage in saline solution has produced higher cell viability in respect to Ringer's lactate at 14 days (91 vs. $81 \%$ ) and at 28 days (83 vs. $29 \%$ ). ${ }^{54}$ Recent studies found that fresh grafts stored for 4 weeks at physiological temperature $\left(37^{\circ} \mathrm{C}\right)$ significantly improved the amount of viable chondrocytes compared with grafts stored at $4^{\circ} \mathrm{C}^{36,55,56}$ Ideal implantation of fresh grafts is within the first 28 days and not more than 6 weeks from harvesting. ${ }^{57,58}$

Currently, small allografts are not blood-type or human leukocyte antigen matched because of the barrier provided by intact hyaline cartilage. ${ }^{20}$

Harvesting is performed removing the knee "en bloc" and washing away with pulse lavage the bone marrow, which is the main source of potential disease transmission and immune response; the graft is then placed in an antibiotic solution for 24 hours before storage. ${ }^{36}$ The lavage significantly decreases the antigenic potential, but the persistence of few cells from the bone marrow may elicit immune responses. ${ }^{18}$ Despite the absence of matching procedures, recipients usually have little or no evidence of graft-versushost disease and no humoral immune response. ${ }^{59-61}$

\section{Surgical Techniques}

Intravenous antibiotic prophylaxis is administered. General or spinal anesthesia is performed. The patient is positioned supine on the operating table with a tourniquet at the proximal thigh. A standard midline straight skin incision is performed followed by a lateral or medial parapatellar arthrotomy. Dowel and shell techniques are the two most commonly used. ${ }^{62}$ While most cartilage lesions can be treated with the dowel technique, large and/or irregular lesions should be treated with the shell technique. ${ }^{63}$

\section{Femoral Dowel Allograft}

The size of the lesion is determined by identifying healthy cartilage walls and by using the templates/sizers usually available in most OCA instrumentations.

After selecting the proper dowel size, a guidewire is positioned perpendicular to the articular surface into the center of the lesion using the sizers. The dowel and the socket are drilled with a reamer to an ideal depth of 6 to $8 \mathrm{~mm}$ without exceeding $10 \mathrm{~mm}$ in depth (-Fig. 2A). When the lesion is deeper than 8 to $10 \mathrm{~mm}$ (i.e., in case of avascular necrosis), the necrotic bone is debrided until healthy, bleeding bone is visible, and autologous bone grafting (from the iliac crest or proximal tibia) is used to fill the defect up to the ideal depth of 6 to $8 \mathrm{~mm}$ from the articular surface. The recipient site is then measured at 12,3,6, and 9 o'clock positions.

The osteochondral donor plug is harvested from the allograft with the use of a workstation and a coring reamer to match the corresponding recipient site (-Fig. $\mathbf{2 B}, \mathbf{C}$ ). The measurement made on the recipient site is then transferred on the osteochondral plug, and the excessive bone is removed. Pulsatile lavages are performed to remove residual bone marrow. For the correct orientation, a 12 o'clock mark is made in both the recipient and the donor plug.

The graft is then gently (with the thumb initially and then with a padded tamp) implanted (press-fit) into the recipient socket $^{64}$ (-Fig. 2D).

When a single plug is not enough to cover the whole lesion, the procedure can be repeated using the "snowman technique" or "mastercard technique" ( - Fig. 2E). Usually, no fixation is required, but bioresorbable pins or screws can be used (-Fig. 2F). The knee is then moved through a complete range of motion (ROM) to verify graft stability and potential impingements.

\section{Femoral Shell Allograft}

For larger or irregular femoral condyle lesions, a shell grafting technique is generally used. After identification of the condylar lesion, a shell graft is handcrafted to minimize the damage to the native healthy cartilage.

The recipient site should have a depth of at least 4 to $5 \mathrm{~mm}$, creating a flat surface; all the necrotic or damaged bone around the lesion should be removed.

The graft is then planned and marked with a paper template and freehand crafted slightly oversized with respect to the recipient area. The graft is then gradually 


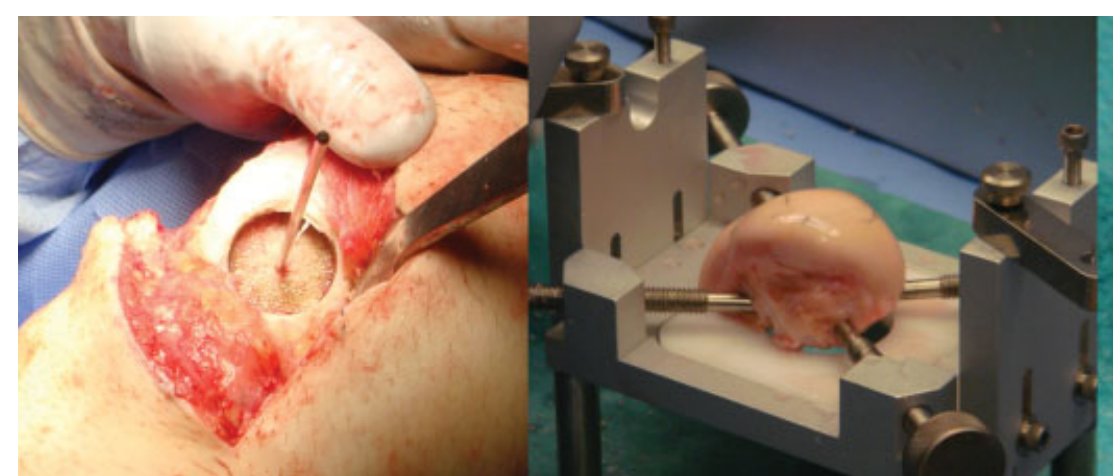

A

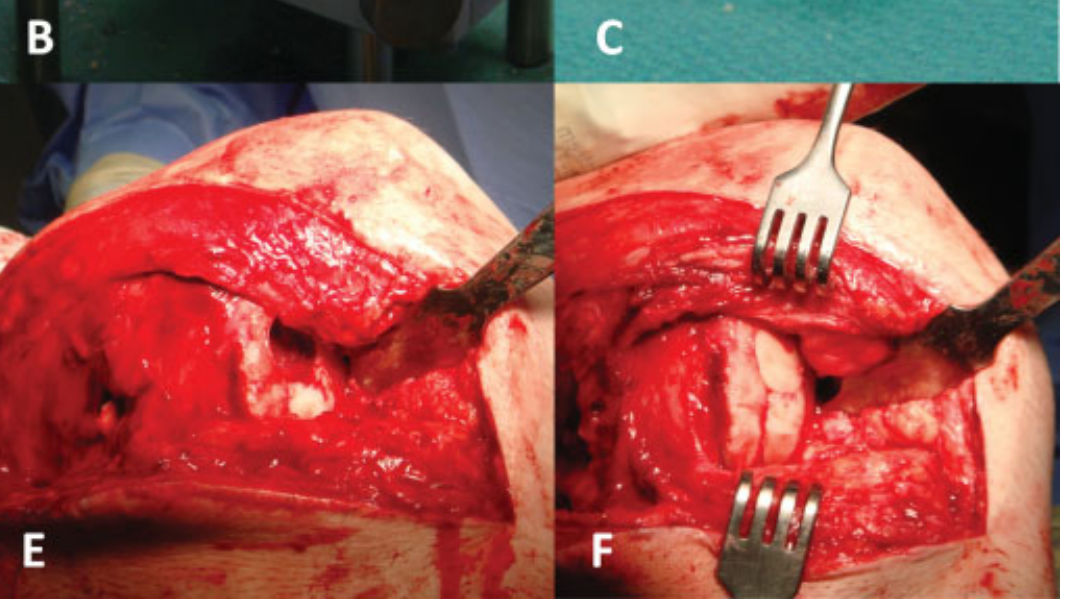

Fig. 2 Intraoperative pictures of osteochondral autograft transplantations and distal femoral opening-wedge varus osteotomy for a lateral femoral condyle osteochondritis dissecans and valgus malalignment. (A) Creation of the recipient site. (B) Femoral condyle allograft on the workstation. (C) Creation of the osteochondral plug. (D) Gentle impaction of the plug in the recipient site (press-fit). (E) When necessary, the procedure can be repeated by creating a new recipient site. $(F)$ Second plug in place.

downsized until a perfect fit is achieved. The transplant is temporarily fixed with Kirschner wires (K-wires), and the knee is moved through complete ROM, ruling out potential impingement. Definitive fixation is performed with bioresorbable pins or compression screws.

\section{Patellar Allograft}

For the treatment of extensive patellar osteochondral defects, a shell technique can be used. The recipient patella is measured, and a bone cut is performed parallel to the patellar and quadriceps tendons, as in patellar resurfacing during total knee replacement. To minimize the risk of host fractures, the resection should leave at least 12 to $15 \mathrm{~mm}$ of the bone. The graft is prepared and fixed in position with the previously described shell technique. Overstuffing should be avoided in order to not put too much pressure on the graft.

\section{Complete Extensor Mechanism Allograft}

This graft is composed of the proximal tibia, the patellar tendon, the patella, and 5 to $8 \mathrm{~cm}$ of the quadriceps tendon. At the recipient site, the residual patella is carefully removed. The midline incision is carried into the recipient quadriceps and over the tibial tubercle. The tibial bone plug of the graft is created first, and then a matching tibial trough is created at the recipient site. Before creating any tibial trough, the allograft tibial bone is prepared as planned to ensure a perfect press-fit.
The length of the bone block should be at least 6 to $8 \mathrm{~cm}$. The depth and the width of the block is approximately 1.5 to $2 \mathrm{~cm}$. The tibial graft is trimmed and proximally dovetailed, and the recipient site is prepared accordingly to prevent proximal migration. Many techniques have been described for tibial tubercle fixation (i.e., screws, stainless cerclages, suture anchors, bone sutures). When fixing allografts, using minimal fixation is important to obtain full integration of the bone and avoid graft breakage. At this point, the quadriceps tendon is fixed with nonabsorbable sutures with pants-over-the-vest technique. ${ }^{65}$ The graft tissue usually loses tension overtime and therefore needs to be tensioned tightly with the knee in full extension, without testing the ROM. ${ }^{66}$

\section{Tibial Allograft}

This technique is usually indicated in tibial plateau (mostly lateral) fracture malunion ( - Fig. 3). The tibial plateau is cut 1 to $2 \mathrm{~cm}$ deep with an oscillating saw depending on the size of the defect. The transverse cut is made perpendicular to the long tibial axis and runs anterior to posterior to match the slope, ensuring adequate coronal and sagittal alignment ( - Fig. 4A). The sagittal plane cut is performed to preserve the tibial eminence and the meniscal root of the opposite compartment. The meniscus of the accepted compartment is removed, preserving the meniscal wall for fixation of the meniscal graft. Once the damaged plateau and meniscus have 


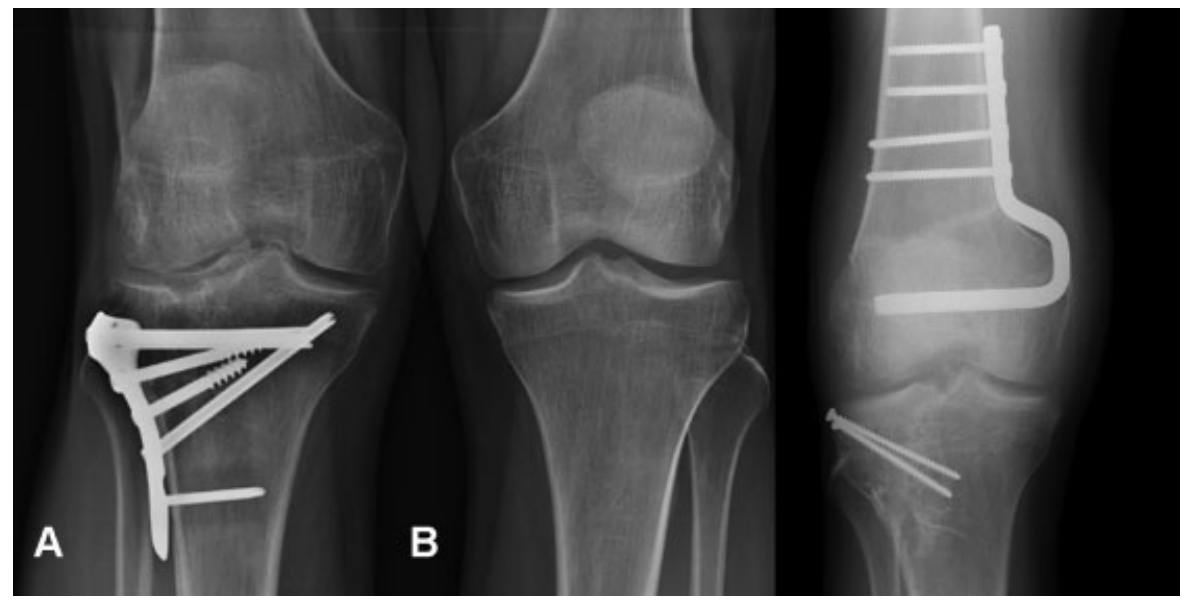

Fig. 3 (A) Preoperative anteroposterior X-ray view of a lateral tibial plateau malunion with valgus malalignment. (B) Postoperative anteroposterior X-ray view after distal femoral closing-wedge varus osteotomy and lateral tibial plateau/meniscus transplant.

been removed from the joint, a step cut osteotomy is then performed to improved graft stability.

The OCA of the tibial plateau is prepared in similar shape and size to restore and preserve the original joint line and meniscal attachment sites (- Fig. 4B). The allograft is temporarily fixed with K-wires, and ROM and stability are tested. The OCA is then fixed to the recipient proximal tibia with two or three $3.5-\mathrm{mm}$ cancellous screws ( $\mathbf{- F i g} . \mathbf{4 C}$ ). The meniscal allograft is then sutured to the residual meniscal wall.

\section{Management of Concomitant Pathology}

Surgical success of the OCA requires diagnosis and management of concomitant pathologies such as meniscal lesions, ligament instability, and malalignment. ${ }^{23,38,67}$

Meniscal pathologies are a relative contraindication for OCA transplant because of the fundamental role of the meniscus in absorption and load distribution; ${ }^{20}$ repairing peripheral lesions may restore the functional proprieties, but, in case of meniscal deficiency, an MAT is required to improve graft survival. ${ }^{23,38,67}$
Malalignment is evaluated during clinical examination and with long-leg weight-bearing X-rays. If the weightbearing line passes in the affected compartment, corrective osteotomy is required to unload and protect the graft. ${ }^{23}$ Generally, for the dowel technique, opening-wedge osteotomy is preferred. Closing-wedge osteotomy in shell or massive OCA should be preferred and performed on the bone opposite to the OCA transplant (i.e., medial closing-wedge distal femoral osteotomy for lateral tibial plateau OCA) to minimize surgical procedure on the same bone..$^{20,44,68-70}$ Maltracking and malalignment should also be addressed when present in patellofemoral OCA (tibial tuberosity-trochlear groove [TT-TG] distance $>20 \mathrm{~mm})^{71}$

Rotational and translational stability is critical for the success of all cartilage procedures, allowing normalization of stress forces and avoiding shear forces that may increase transplant damage over time; ${ }^{72}$ therefore, ligament reconstruction is mandatory in case of associated knee instability. ${ }^{20,72}$ Pearls and pitfalls in the surgical techniques are described in $=$ Table 1 .

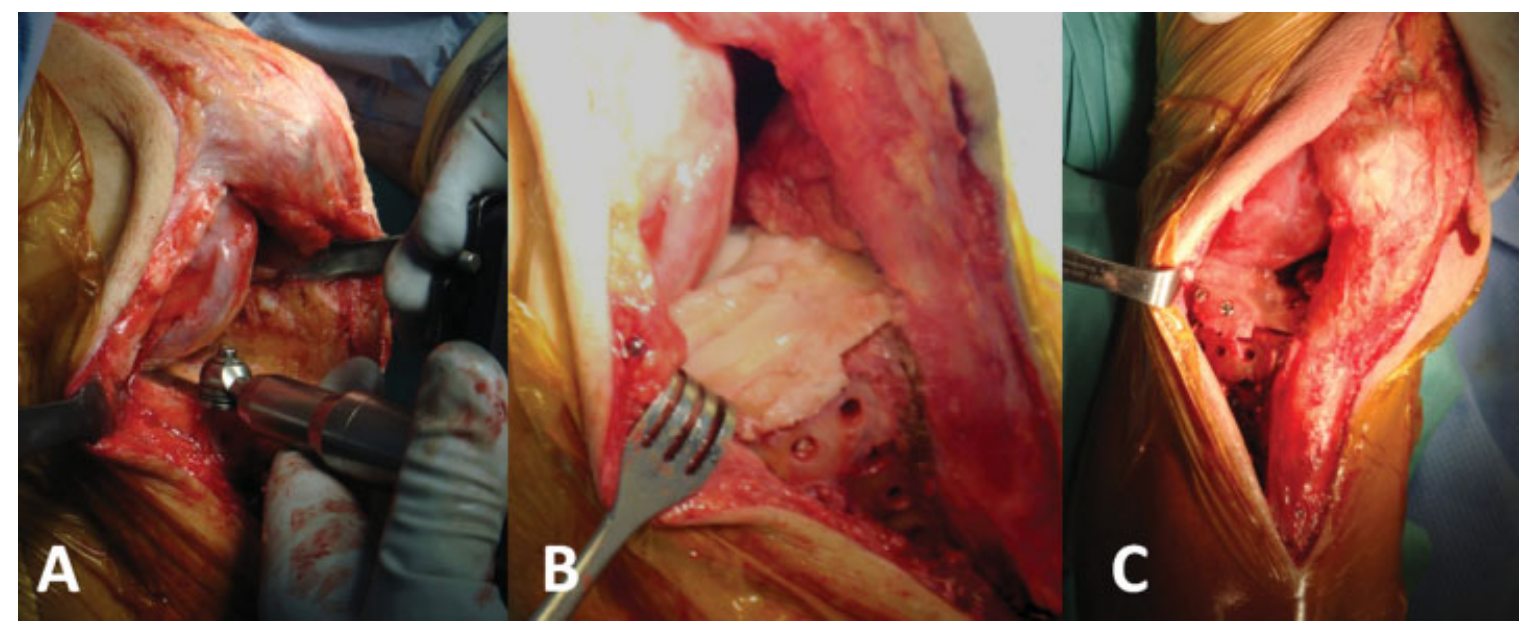

Fig. 4 Intra-articular phase of the case described in Fig. 3. (A) Resection of the damaged lateral tibial plateau. (B) Lateral tibial plateau + lateral meniscus transplant (not the step-cut osteotomy to improve graft stability). (C) Fixation of the graft with two 3.5-mm cortical screws. 
Table 1 Pearls and pitfalls in the surgical technique

\begin{tabular}{|l|l|}
\hline Pearls & Pitfalls \\
\hline $\begin{array}{l}\text { Copiously irrigate cutting surfaces with saline solution while } \\
\text { using reamer or saw to avoid edges heat necrosis }\end{array}$ & Delay the management of concomitant pathologies \\
\hline Use a manual rasp to fine tune the graft size & Leave pathological tissue in the recipient site \\
\hline $\begin{array}{l}\text { Copiously irrigate the graft before the transplant to remove } \\
\text { the last remaining bone marrow cells }\end{array}$ & Use OCA plugs $>10 \mathrm{~mm}$ of thickness \\
\hline $\begin{array}{l}\text { Find landmarks on both the graft and the recipient site to } \\
\text { harvest the corresponding area }\end{array}$ & Uncorrected orientation of the graft into the recipient site \\
\hline $\begin{array}{l}\text { The extensor mechanism allograft must be tensioned tightly } \\
\text { with the knee in full extension, avoiding ROM maneuvers at } \\
\text { the end }\end{array}$ & $\begin{array}{l}\text { Forcing the Implant of the graft and causing a damage to the } \\
\text { cartilage superficial layer }\end{array}$ \\
\hline $\begin{array}{l}\text { Insert autologous bone graft in the recipient socket to } \\
\text { improve graft stability in case of unperfected graft fitting or } \\
\text { deep ( }>10 \mathrm{~mm}) \text { lesions }\end{array}$ & Press-fit fixation of a downsized graft \\
\hline
\end{tabular}

Abbreviation: OCA, osteochondral allograft.

\section{Postoperative Rehabilitation}

Postoperative rehabilitation starts immediately after surgery. Several authors recommend the use of a knee brace, but no consensus exists on its use. ${ }^{24,73}$

Early progressive nonweight-bearing ROM is encouraged to promote healing process and graft vascularization. Nonweight-bearing is necessary until standard X-rays demonstrate graft incorporation; this ranges from 6 to 12 weeks according to graft size. ${ }^{18,36}$ Patients treated for patellofemoral joint lesions can weight-bear as tolerated with the knee brace locked in full extension. ${ }^{73}$ Return to sport is usually 1 year after surgery, when full ROM, complete stability, no effusion, and optimal dynamic quadriceps strength are achieved. $^{74}$

In case of complete extensor mechanism allograft, a fullextension knee brace is maintained for 8 weeks, avoiding full weight-bearing. At 8 weeks, 30-degree active flexion is allowed in a hinged knee brace, and patients can gradually start weight-bearing. At 12 weeks, flexion is increased to 90 degrees; full flexion is gradually achieved at 6 months from index surgery.

In case of concomitant surgical procedures (limb realignment, ligamentous reconstructions, and/or meniscal surgery) weigh-bearing and ROM restriction could be modified accordingly.

\section{Complications}

Larger grafts are at a higher risk of collapse and fragmentation, ${ }^{33}$ which are the main causes of failure with a rate of approximately $25 \%$ at 12.3 years of follow-up. ${ }^{21}$ In a recent study, Tírico et al reported that the size of the lesion does not influence the outcomes of OCA for isolated femoral defects. ${ }^{75}$

Onset of pain, joint effusion, and mechanical symptoms are signs of graft failure due to subchondral collapse or nonunion. Although the integration of the allograft at the cartilage-to-cartilage interface is usually not complete, OCAs fail when integration does not occur at the bone-to-bone interface. Radiographs may show sclerosis, narrowing or obliteration of the joint space, osteophytes, and subchondral cyst formation. ${ }^{40}$ Patients who are 30 years or older at the time of surgery have 3.5 times higher risk of allograft failure compared with younger patients. Similarly, two or more previous surgeries on the affected knee increase the risk of grafts failure by 2.5 times. $^{27}$

Allograft subsidence may be a milder complication causing persistent slight pain due to a low-grade chronic inflammatory reaction to the graft. ${ }^{17}$ Immunological reactions could be the main cause of failure in large OCA with associated soft tissue transplant, as in bipolar OCA of the knee. Progressive OA and instability make these specific knee OCAs unsuitable for the treatment of posttraumatic end-stage OA. ${ }^{76}$ The treatment options for these cases include observational approach, removal of the graft, allograft revision, or knee arthroplasty (partial or total). The overall reoperation rate is approximately 35\%: $68 \%$ of the patients are treated with total knee arthroplasty (TKA), $4 \%$ with unicompartmental knee arthroplasty, and $28 \%$ with graft removal, new fixation, or revision. ${ }^{20}$

Infection is a serious complication and has to be carefully ruled out as the first step in failed OCA. This is performed with clinical examination, blood tests for inflammation (C-reactive protein, erythrocyte sedimentation rate, white blood cells), and joint aspiration when needed. Deep and superficial infections have to be differentiated because of the different treatments required. Irrigation, surgical debridement, or graft removal is necessary in case of deep infection.

The risk of disease transmission is rare due to the strict donor screening protocols. The estimated risk of viral transmission due to donor viremia at time of donation is $1 / 63,000$ for hepatitis B virus, 1/103,000 for hepatitis C virus, $1 / 493,000$ for human immunodeficiency virus (HIV), and $1 / 129,000$ for human T-lymphotropic virus. ${ }^{77}$ The estimated risk of disease transmission with allograft tissue transplantations is low; Buck et $\mathrm{al}^{78}$ reported a risk of 1/1.6 million. Only one case of HIV transmission was reported, and it was before the introduction of standard screenings in $1985 .{ }^{79,80}$ 


\section{Literature Review}

Femoral and tibial OCA results are summarized in - Tables 2 and 3 , respectively. OCA transplantation in the knee has demonstrated reliable mid- to long-term results in terms of graft survival and return to activity. The femoral condyle is the most common site of OCA transplantation in the knee.

Davidson et $\mathrm{al}^{81}$ reevaluated femoral OCA transplant with second-look arthroscopy, radiological analysis, and biopsies. MRI and standard X-rays showed improvement of the mean Outerbridge MRI score from 4.3 preoperatively to 0.6 . Histological analysis did not show significant differences between the graft and native cartilage. All the clinical scores analyzed (International Knee Documentation Criteria [IKDC], Lysholm, and 36-Item Short Form Health Survey [SF-36]) improved significantly.

Recent studies by Krych et $\mathrm{al}^{74}$ Nielsen et $\mathrm{al}^{82}$ and McCarthy et $\mathrm{al}^{83}$ showed nearly $80 \%$ of return to sport at preinjury level. Collegiate and professional athletes were all able to return to play. Risk factors affecting the ability to return to sport were age older than 25 years, preoperative duration of symptoms longer than 12 months, female sex, and graft dimension.

McCulloch et $\mathrm{al}^{25}$ in 25 consecutive OCA transplants for femoral condyle defects showed graft incorporation in 22 patients at a minimum 2-year follow-up. Significant improvements were also reported in all subjective outcome scores.

Emmerson et $\mathrm{al}^{84}$ studied 66 femoral OCDs treated with OCA transplant, and the survivorship analysis showed $91 \%$ survivorship at 2 years and $76 \%$ at 15 years. More than $90 \%$ of the patients were satisfied and had pain relief.

Murphy et al $^{12}$ in a series of 39 young patients showed an OCA survivorship of $90 \%$ at 10 years. The authors reported improvement in all outcomes assessed: IKDC, modified Merle Merle D'Aubigné and Postel, and Knee Society function scores. Four out of five failed grafts were successfully revised with an additional allograft transplant.

Levy et $\mathrm{al}^{27}$ reported the largest retrospective series of OCA transplants of the femoral condyles. In total, 123 patients were followed for at least 10 years after fresh OCA, and the survivorship was $82 \%$.

Raz et al $^{13}$ performed 58 distal femoral OCA transplants and reevaluated them at a mean of 21.8 years. The authors reported excellent long-term survival rates, a reoperation rate of $22 \%$, and good knee function in patients with graft survival.

Gross et $\mathrm{al}^{23}$ performed 72 femoral OCA transplants in a prospective study with 10 years of follow-up. Survivorship analysis showed $85 \%$ of graft survival at 10 years. One-fifth of the grafts required revision surgery or TKA, and in 40 of the remaining grafts, good-to-excellent results were achieved with the Hospital for Special Surgery (HSS) score.

Ghazavi et al $^{34}$ performed OCA transplants to reconstruct posttraumatic defects (tibia, femur, and patella) in more than 100 patients with long-term follow-up. Of the 126 knees, $86 \%$ were successfully reconstructed. They reported $50 \%$ of failure rate in bipolar OCA. Survivorship analysis showed 95\% graft survival at 5 years, and $66 \%$ at 20 years with a postoperatively HSS knee score increased from 66 to 83 points. Gracitelli et $\mathrm{l}^{85}$ performed a similar study on OCA transplant to treat posttraumatic defect. One-quarter of the OCAs is considered failed, and the reoperation rate was $50 \%$. Eighty percent of the patients reported satisfactory results at a median followup of 6.6 years; the reported survivorship was $80 \%$ at 5 years and $70 \%$ at 10 years. Wang et $\mathrm{al}^{86}$ treated 54 patients aged $>40$ years with OCA to treat femoral and patella osteochondral defects. They reported higher failure and reoperation rates compared with other series of younger patients and a 4-year survivorship rate of $73 \%$.

Gross et $\mathrm{al}^{23}$ treated 67 knees with tibial posttraumatic OA due to tibial plateau fractures and reported graft survival of $95 \%$ at 5 years and $46 \%$ at 20 years. About one-third of them required knee arthroplasty after graft failure at approximately 10 years after OCA transplant. Drexler et $\mathrm{al}^{69}$ performed 27 combined procedure of OCA transplant and distal femoral osteotomy for tibial posttraumatic OA with a longterm follow-up. They reported approximately $90 \%$ of goodto-excellent score at 2 years and approximately $90 \%$ of graft survival at 10-year follow-up. However, survivorship declined significantly over time to $23.8 \%$ at 20 years. They reported a similar decline in the Knee Society function score and the Knee Society score. Getgood et $\mathrm{al}^{38}$ in a recent retrospective series of OCA and concomitant MAT reported a high total reoperation rate, but $78 \%$ of patients were satisfied or extremely satisfied at the final follow-up. Similar results were reported by Harris et $\mathrm{al}^{68}$ in patients treated with combined corrective osteotomy, MAT, and cartilage procedures (12 OCAs). Frank et $\mathrm{al}^{87}$ compared, with a mean follow-up of 5 years, patients who underwent femoral OCA and associated MAT with patients without associated MAT. Graft survivorship was $86 \%$ at 5 years. They did not find any significant difference between the groups regarding patient-reported clinical outcomes score, failure rates, reoperation rate, and time to reoperation.

Colangeli et $\mathrm{al}^{88}$ compared OCA transplants and knee modular megaprosthesis for the reconstruction of the knee after proximal tibia bone tumors in young patients at a mean follow-up of 37 and 63 months, respectively. They found a lower incidence of knee extension lag, a greater quadriceps strength, and a higher rate of normal knee pattern during gait with OCA. In their series, OCA transplant had better outcomes compared with knee megaprosthesis. Muscolo et $\mathrm{al}^{89}$ reviewed 58 OCA transplants after proximal tibia resection due to bone tumors, and a survival analysis revealed $65 \%$ graft survivorship at 10 years. Other series of limb salvage procedures with OCA transplant after proximal tibia bone tumors reported success rates from 66 to $80 \% .{ }^{90,91}$

Imanishi et $\mathrm{al}^{92}$ reported four limb salvage procedures with reconstruction of extensor mechanism using bonepatellar tendon-bone (BРTB) allograft after sarcoma resection with satisfactory results and complete ROM in all patients at 18 - to 67-month follow-up. At 1 year after surgery, all junctions between bone allograft and residual bones were united. Drexler et al $^{93}$ used an extensor mechanism BPTB allograft to reconstruct a posttraumatic defect of 
Table 2 Femoral osteochondral allograft results

\begin{tabular}{|c|c|c|c|c|c|}
\hline Author (year) & $\begin{array}{l}\text { No. of cases } \\
\text { (mean age) }\end{array}$ & $\begin{array}{l}\text { Pathology } \\
\text { (mean size) }\end{array}$ & Technique & Follow-up & Results \\
\hline $\begin{array}{l}\text { Davidson et al } \\
\text { (2007) }\end{array}$ & $10(32.6)$ & $\begin{array}{l}\text { OCD, trauma } \\
\left(5.4 \mathrm{~cm}^{2}\right)\end{array}$ & Dowel & $40 \mathrm{mo}$ & $\begin{array}{l}\text { Outerbridge MRI: } 4.3 \rightarrow 0.6 \text { IKDC: } \\
27 \rightarrow 79 \text { Lysholm score: } 37 \rightarrow 78 \\
\text { SF-36: } 38 \rightarrow 51\end{array}$ \\
\hline $\begin{array}{l}\text { McCulloch et al } \\
\text { (2007) }\end{array}$ & $25(35)$ & $\begin{array}{l}\text { OCD, trauma, } \\
\text { osteonecrosis } \\
\left(5.2 \mathrm{~cm}^{2}\right)\end{array}$ & Dowel & $2.9 \mathrm{y}$ & $\begin{array}{l}\text { Graft incorporation: } 88 \% \\
\text { Survivorship: } 96 \% \text { at } 2 \text { y } \\
\text { KOOS: } 43 \rightarrow 73 \\
\text { SF- } 12: 36 \rightarrow 40 \\
\text { IKDC: } 29 \rightarrow 58 \\
\text { Lysholm score: } 39 \rightarrow 67 \text { Failure } \\
\text { rate: } 4 \%\end{array}$ \\
\hline $\begin{array}{l}\text { Krych et al } \\
(2012)\end{array}$ & 43 (32.9) & $\begin{array}{l}\text { OCD, trauma } \\
\text { idiopathic } \\
\left(7.2 \mathrm{~cm}^{2}\right)\end{array}$ & Dowel & $2.5 \mathrm{y}$ & $\begin{array}{l}\text { Return to play: } 80 \% \text {; professional } \\
\text { athletes } 100 \% \\
\text { Survivorship: } 100 \% \text { at } 2 \text { y IKDC: } \\
46 \rightarrow 79 \\
\text { KOOS ADL: } 62 \rightarrow 82\end{array}$ \\
\hline $\begin{array}{l}\text { McCarthy et al } \\
\text { (2017) }\end{array}$ & 13 (19) & $\mathrm{N} / \mathrm{A}$ & Dowel & $5.9 y$ & $\begin{array}{l}\text { IKDC: } 38 \rightarrow 63 \text { Lysholm score: } \\
41 \rightarrow 64 \text { SF-12: } 35 \rightarrow 44 \text { Return to } \\
\text { play: } 77 \%\end{array}$ \\
\hline $\begin{array}{l}\text { Emmerson et al } \\
(2007)\end{array}$ & 66 (28.6) & $\begin{array}{l}\text { OCD } \\
\left(7.5 \mathrm{~cm}^{2}\right)\end{array}$ & $\begin{array}{l}\text { Dowel } \\
\text { Shell }\end{array}$ & 7.7 y & $\begin{array}{l}\text { Survivorship: } 91 \% \text { at } 2 \text { y; } 76 \% \text { at } \\
15 y \\
\text { D\&P: } 13 \rightarrow 17 \\
\text { Failure rate: } 15 \%\end{array}$ \\
\hline $\begin{array}{l}\text { Levy et al } \\
\text { (2013) }\end{array}$ & $129(33)$ & $\begin{array}{l}\text { OCD, trauma, } \\
\text { osteonecrosis, } \\
\text { idiopathic } \\
\left(8.1 \mathrm{~cm}^{2}\right)\end{array}$ & $\begin{array}{l}\text { Dowel } \\
\text { Shell }\end{array}$ & $13.5 y$ & $\begin{array}{l}\text { Survivorship: } 82 \% \text { at } 10 \text { y, } 74 \% \text { at } \\
15 y, 66 \% \text { at } 20 \text { y } \\
\text { KSF: } 66 \rightarrow 83 \\
\text { D\&P: } 12 \rightarrow 16 \text { Failure rate: } 24 \%\end{array}$ \\
\hline $\begin{array}{l}\text { Murphy et al } \\
(2014)\end{array}$ & 39 (16.4) & $\begin{array}{l}\text { OCD, trauma, } \\
\text { osteonecrosis, } \\
\text { idiopathic } \\
\left(8.4 \mathrm{~cm}^{2}\right)\end{array}$ & $\begin{array}{l}\text { Dowel } \\
\text { Shell }\end{array}$ & $8.4 \mathrm{y}$ & $\begin{array}{l}\text { Survivorship analysis: } \\
90 \% \text { at } 10 \text { y IKDC: } 42 \rightarrow 75 \\
\text { D\&P: } 13 \rightarrow 17 \\
\text { KSF: } 69 \rightarrow 89 \\
\text { Failure: } 12 \%\end{array}$ \\
\hline Raz et al (2014) & $58(28)$ & OCD, trauma & $\begin{array}{l}\text { Dowel } \\
\text { Shell }\end{array}$ & 21.8 y & $\begin{array}{l}\text { Survivorship: } 91 \% \text { at } 10 \mathrm{y} ; \\
84 \% \text { at } 15 \text { y; } 69 \% \text { at } 20 y ; \\
59 \% \text { at } 25 \text { y Failure rate: } 22 \%\end{array}$ \\
\hline $\begin{array}{l}\text { Nielsen et al } \\
(2017)\end{array}$ & $149(31)$ & $\begin{array}{l}\text { OCD, trauma, } \\
\text { idiopathic, } \\
\text { osteonecrosis }\end{array}$ & $\begin{array}{l}\text { Dowel } \\
\text { Shell }\end{array}$ & $6 y$ & $\begin{array}{l}\text { Return to play: } 75 \% \text { IKDC: } \\
42 \rightarrow 74 \text { D\&P: } 13 \rightarrow 17 \\
\text { KSF: } 72 \rightarrow 91 \text { Failure rate: } 9.4 \%\end{array}$ \\
\hline $\begin{array}{l}\text { Gross et al } \\
(2005)\end{array}$ & $60(42.8)$ & $\begin{array}{l}\text { OCD, trauma, } \\
\text { idiopathic, } \\
\text { osteonecrosis }\end{array}$ & Shell & $11.8 \mathrm{y}$ & $\begin{array}{l}\text { Survivorship: } 95 \% \text { at } 5 \text { y; } 85 \% \text { at } \\
10 \text { y; } 74 \% \text { at } 15 \text { y Reoperation } \\
\text { rate: } 20 \% \\
\text { HSS: } 83\end{array}$ \\
\hline
\end{tabular}

Abbreviations: ADL, Activity Daily living; D\&P, D’Aubigné and Postel score; HSS, Hospital for Special Surgery score; IKDC, International Knee Documentation Criteria; KOOS, Knee Injury and Osteoarthritis Outcome Score; KSF, Knee Society function score; MRI, magnetic resonance imaging; N/A, not applicable; OCD, osteochondritis dissecans; SF-12, 12-Item Short Form Health Survey; SF-36, 36-Item Short Form Health Survey.

the extensor mechanism in a young and active patient with a failed posttraumatic partial patellectomy. At 6 months after surgery, the union of the allograft was seen on X-rays, and the patient returned to his previous sporting activities with a full ROM. Rosenberg ${ }^{94}$ reviewed at a mean of 5-year followup 50 patients treated with extensor mechanism BPTB allograft in extensor mechanism rupture after TKA. The author reported a high rate of complication and $19 \%$ of failure, and only $56 \%$ of the patients had full active extension. Despite these poor outcomes, other authors reported encouraging results in the management of failed extensor mechanism after TKA using BPTB allograft. ${ }^{95,96}$

Bakay et al, ${ }^{40}$ using mushroom-shaped cryopreserved OCA, performed eight whole patellar surface replacement with a success rate of $75 \%$ at a mean follow-up of 19 months.

During the last decade, the use of OCA in the patellofemoral joint has notably increased. Jamali et $\mathrm{al}^{71}$ in a case series of patellofemoral OCA reported improvement in patient-reported outcomes score, but one-quarter of the operated knees required a major revision within 2 to 5 years postoperatively. 
Table 3 Tibial osteochondral allograft results

\begin{tabular}{|l|l|l|l|l|l|}
\hline Author (year) & $\begin{array}{l}\text { No. of cases } \\
\text { (mean age) }\end{array}$ & $\begin{array}{l}\text { Pathology } \\
\text { (mean size) }\end{array}$ & $\begin{array}{l}\text { Adjuvant } \\
\text { procedures }\end{array}$ & Follow-up & Results \\
\hline $\begin{array}{l}\text { Gross et al } \\
(2005)\end{array}$ & $65(42.8)$ & Trauma & MAT, DFO/HTO & $11.8 \mathrm{y}$ & $\begin{array}{l}\text { Survivorship: } 95 \% \text { at } 5 \text { y, } 80 \% \text { at } \\
10 \text { y, } 65 \% \text { at } 15 \mathrm{y} \\
\text { HSS: } 85.3\end{array}$ \\
\hline $\begin{array}{l}\text { Drexler et al } \\
(2015)\end{array}$ & $\begin{array}{l}27 \\
(35.8)\end{array}$ & $\begin{array}{l}\text { Trauma } \\
\left(15 \mathrm{~cm}^{2}\right)\end{array}$ & DFO & $13.3 \mathrm{y}$ & $\begin{array}{l}\text { Survivorship: } 89 \% \text { at } 10 \mathrm{y}, 23.8 \% \\
\text { at } 20 \mathrm{y} \text { KSF: } 51 \rightarrow 71 \\
\text { KSS: } 55 \rightarrow 84\end{array}$ \\
\hline $\begin{array}{l}\text { Getgood et al } \\
(2015)\end{array}$ & $48(35.8)$ & $\begin{array}{l}\text { Trauma, } \\
\text { idiopathic } \\
\left(15 \mathrm{~cm}^{2}\right)\end{array}$ & MAT & $6.8 \mathrm{y}$ & $\begin{array}{l}\text { Survivorship: } 73 \% \text { at } 5 \text { y, } 68 \% \\
\text { at } 10 \mathrm{y} \\
\text { IKDC: } 33 \rightarrow 58 \\
\text { D\&P: } 12 \rightarrow 15 \\
\text { Reoperation rate: } 54 \%\end{array}$ \\
\hline $\begin{array}{l}\text { Frank et al } \\
(2018)\end{array}$ & $100(31.7)$ & Idiopathic & MAT & $4.9 \mathrm{y}$ & $\begin{array}{l}\text { Survivorship: } 86 \% \text { at } 5 \text { y IKDC: } \\
40 \rightarrow 66 \text { Reoperation rate: } 35 \%\end{array}$ \\
\hline
\end{tabular}

Abbreviations: D\&P, Merle D’Aubigné and Postel score; DFO, distal femoral osteotomy; HSS, Hospital for Special Surgery score; HTO, high tibial osteotomy; IKDC, International Knee Documentation Criteria; KSF, Knee Society function score; KSS, Knee Society score; MAT, meniscal allograft transplant.

Similar results were also reported by Torga Spak and Teitge. ${ }^{97}$ These reports were not convincing compared with cell-based techniques, but recent reports have encouraged the use of OCA for patellofemoral joint. ${ }^{98}$ Gracitelli et al $^{99}$ in a long-term review of the cohort reported by Jamali et $\mathrm{al}^{71}$ reported average graft survival of $80 \%$ at 10 years with a substantial improvement in pain and patient satisfaction. In a case series of isolated trochlear OCA, the survivorship analysis reported $100 \%$ at 5 years and $90 \%$ at 10 years. ${ }^{100}$

Beaver et al $^{41}$ performed 19 bipolar OCAs with an average follow-up of 68 months. Graft survivorship analysis was $60 \%$ at 5 years and decreased to $40 \%$ at 10 years. Compared with unipolar defects, bipolar OCAs showed a significantly lower success rate. Giannini et $\mathrm{al}^{76}$ treated a case series of seven knees with end-stage OA using large bipolar OCA. They found joint laxity and aseptic effusion associated with chondrolysis, leading to early failure in six knees. A TKA was necessary in these patients within 2 years of follow-up. The patient who received the allograft to revise a knee fusion was the only one with satisfactory results at follow-up control.

\section{Conclusion}

OCA has shown to be a safe and effective treatment for large and/or full-thickness and/or osteochondral knee defects using viable mature hyaline cartilage supported by an intact subchondral bone and avoiding donor-site morbidity. In complex or salvage procedures, OCA transplant allows for the restoration of native bone stock. The treatment reduces pain and improves function, especially in young and active selected patients. In patellofemoral lesions, OCA has to be considered only in revision surgery or when a complete patella resurfacing is necessary. Costs, grafts availability, systemic pathologies, and multicompartmental OA limit the use of OCA. Management of concomitant pathologies such as instability, malalignment, and meniscal pathologies is crucial to the success of OCA transplant.
Mid- and long-term results are encouraging with good-toexcellent results and graft survival. Ideal indications are unipolar lesions, in patients younger than 30 years old, in traumatic etiology, and lesions treated before 12 months from the onset of symptoms.

Future basic science research should be performed to improve allograft processing and storage with the goal of improving cells viability. Improvement in graft incorporation and fixation are also necessary. Bioactive growing factors, stem cells, three-dimensional scaffolds, and chemical modular healing agents are new technologies requiring additional prospective studies to confirm the promising initial results.

\section{References}

1 LaPrade RF, Botker J, Herzog M, Agel J. Refrigerated osteoarticular allografts to treat articular cartilage defects of the femoral condyles. A prospective outcomes study. J Bone Joint Surg Am 2009;91(04):805-811

2 Curl WW, Krome J, Gordon ES, Rushing J, Smith BP, Poehling GG. Cartilage injuries: a review of 31,516 knee arthroscopies. Arthroscopy 1997;13(04):456-460

3 Arøen A, Løken S, Heir S, et al. Articular cartilage lesions in 993 consecutive knee arthroscopies. Am J Sports Med 2004;32(01): 211-215

4 Hjelle K, Solheim E, Strand T, Muri R, Brittberg M. Articular cartilage defects in 1,000 knee arthroscopies. Arthroscopy 2002; 18(07):730-734

5 Harris JD, Brophy RH, Siston RA, Flanigan DC. Treatment of chondral defects in the athlete's knee. Arthroscopy 2010;26 (06):841-852

6 Gudas R, Gudaite A, Pocius A, et al. Ten-year follow-up of a prospective, randomized clinical study of mosaic osteochondral autologous transplantation versus microfracture for the treatment of osteochondral defects in the knee joint of athletes. Am J Sports Med 2012;40(11):2499-2508

7 Knutsen G, Drogset JO, Engebretsen L, et al. A randomized trial comparing autologous chondrocyte implantation with microfracture. Findings at five years. J Bone Joint Surg Am 2007;89 (10):2105-2112 
8 Alford JW, Cole BJ. Cartilage restoration, part 2: techniques, outcomes, and future directions. Am J Sports Med 2005;33 (03):443-460

9 Nehrer S, Spector M, Minas T. Histologic analysis of tissue after failed cartilage repair procedures. Clin Orthop Relat Res 1999; (365):149-162

10 Mithoefer K, Williams RJ III, Warren RF, et al. The microfracture technique for the treatment of articular cartilage lesions in the knee. A prospective cohort study. J Bone Joint Surg Am 2005;87 (09):1911-1920

11 Chow JC, Hantes ME, Houle JB, Zalavras CG. Arthroscopic autogenous osteochondral transplantation for treating knee cartilage defects: a 2- to 5-year follow-up study. Arthroscopy 2004;20 (07):681-690

12 Murphy RT, Pennock AT, Bugbee WD. Osteochondral allograft transplantation of the knee in the pediatric and adolescent population. Am J Sports Med 2014;42(03):635-640

13 Raz G, Safir OA, Backstein DJ, Lee PT, Gross AE. Distal femoral fresh osteochondral allografts. Follow-up at a mean of twentytwo-years. J Bone Joint Surg Am 2014;96(13):1101-1107

14 Agneskirchner JD, Brucker P, Burkart A, Imhoff AB. Large osteochondral defects of the femoral condyle: press-fit transplantation of the posterior femoral condyle (MEGA-OATS). Knee Surg Sports Traumatol Arthrosc 2002;10(03):160-168

15 Minas T. Autologous chondrocyte implantation for focal chondral defects of the knee. Clin Orthop Relat Res 2001 ; (391, Suppl): S349-S361

16 Biant LC, McNicholas MJ, Sprowson AP, Spalding T. The surgical management of symptomatic articular cartilage defects of the knee: Consensus statements from United Kingdom knee surgeons. Knee 2015;22(05):446-449

17 Chui K, Jeys L, Snow M. Knee salvage procedures: The indications, techniques and outcomes of large osteochondral allografts. World J Orthop 2015;6(03):340-350

18 Capeci CM, Turchiano M, Strauss EJ, Youm T. Osteochondral allografts: applications in treating articular cartilage defects in the knee. Bull Hosp Jt Dis (2013) 2013;71(01):60-67

19 Dean CS, Chahla J, Serra Cruz R, LaPrade RF. Fresh osteochondral allograft transplantation for treatment of articular cartilage defects of the knee. Arthrosc Tech 2016;5(01):e157-e161

20 Sherman SL, Garrity J, Bauer K, Cook J, Stannard J, Bugbee W. Fresh osteochondral allograft transplantation for the knee: current concepts. J Am Acad Orthop Surg 2014;22(02):121-133

21 Assenmacher AT, Pareek A, Reardon PJ, Macalena JA, Stuart MJ, Krych AJ. Long-term outcomes after osteochondral allograft: a systematic review at long-term follow-up of 12.3 years. Arthroscopy 2016;32(10):2160-2168

22 Chahal J, Gross AE, Gross C, et al. Outcomes of osteochondral allograft transplantation in the knee. Arthroscopy 2013;29(03): 575-588

23 Gross AE, Shasha N, Aubin P. Long-term followup of the use of fresh osteochondral allografts for posttraumatic knee defects. Clin Orthop Relat Res 2005;(435):79-87

24 Williams RJ III, Ranawat AS, Potter HG, Carter T, Warren RF. Fresh stored allografts for the treatment of osteochondral defects of the knee. J Bone Joint Surg Am 2007;89(04):718-726

25 McCulloch PC, Kang RW, Sobhy MH, Hayden JK, Cole BJ. Prospective evaluation of prolonged fresh osteochondral allograft transplantation of the femoral condyle: minimum 2-year followup. Am J Sports Med 2007;35(03):411-420

26 Görtz S, De Young AJ, Bugbee WD. Fresh osteochondral allografting for steroid-associated osteonecrosis of the femoral condyles. Clin Orthop Relat Res 2010;468(05):1269-1278

27 Levy YD, Görtz S, Pulido PA, McCauley JC, Bugbee WD. Do fresh osteochondral allografts successfully treat femoral condyle lesions? Clin Orthop Relat Res 2013;471(01):231-237

28 De Caro F, Bisicchia S, Amendola A, Ding L. Large fresh osteochondral allografts of the knee: a systematic clinical and basic science review of the literature. Arthroscopy 2015;31(04): 757-765

29 Bugbee WD. Fresh osteochondral allografts. J Knee Surg 2002;15 (03):191-195

30 Gross AE. Use of fresh osteochondral allografts to replace traumatic joint defects. In: Gross AE, Czitrom AA, eds. Allografts in Orthopaedic Practice. Baltimore, MD: Lippincott Williams \& Wilkins; 1992:67-82

31 Shasha N, Aubin PP, Cheah HK, Davis AM, Agnidis Z, Gross AE. Long-term clinical experience with fresh osteochondral allografts for articular knee defects in high demand patients. Cell Tissue Bank 2002;3(03):175-182

32 Cole BJ, Pascual-Garrido C, Grumet RC. Surgical management of articular cartilage defects in the knee. J Bone Joint Surg Am 2009; 91(07):1778-1790

33 Demange M, Gomoll AH. The use of osteochondral allografts in the management of cartilage defects. Curr Rev Musculoskelet Med 2012;5(03):229-235

34 Ghazavi MT, Pritzker KP, Davis AM, Gross AE. Fresh osteochondral allografts for post-traumatic osteochondral defects of the knee. J Bone Joint Surg Br 1997;79(06):1008-1013

35 Garrett JC. Osteochondral allografts for reconstruction of articular defects of the knee. Instr Course Lect 1998;47:517-522

36 Görtz S, Bugbee WD. Fresh osteochondral allografts: graft processing and clinical applications. J Knee Surg 2006;19(03):231-240

37 Krych AJ, Robertson CM, Williams RJ III; Cartilage Study Group. Return to athletic activity after osteochondral allograft transplantation in the knee. Am J Sports Med 2012;40(05):1053-1059

38 Getgood A, Gelber J, Gortz S, De Young A, Bugbee W. Combined osteochondral allograft and meniscal allograft transplantation: a survivorship analysis. Knee Surg Sports Traumatol Arthrosc 2015;23(04):946-953

39 Convery FR, Akeson WH, Meyers MH. The operative technique of fresh osteochondral allografting of the knee. Oper Tech Orthop 1997; 7:340-344

40 Bakay A, Csönge L, Papp G, Fekete L. Osteochondral resurfacing of the knee joint with allograft. Clinical analysis of 33 cases. Int Orthop 1998;22(05):277-281

41 Beaver RJ, Mahomed M, Backstein D, Davis A, Zukor DJ, Gross AE. Fresh osteochondral allografts for post-traumatic defects in the knee. A survivorship analysis. J Bone Joint Surg Br 1992;74(01): 105-110

42 Campbell AB, Knopp MV, Kolovich GP, et al. Preoperative MRI underestimates articular cartilage defect size compared with findings at arthroscopic knee surgery. Am J Sports Med 2013;41 (03):590-595

43 Gomoll AH, Yoshioka H, Watanabe A, Dunn JC, Minas T. Preoperative measurement of cartilage defects by MRI underestimates lesion size. Cartilage 2011;2(04):389-393

44 Bonasia DE, Castoldi F, Dragoni M, Amendola A. Management of the complications following fractures around the knee (malalignment and unicompartimental arthritis). In: Castoldi F, Bonasia DE, eds. Fractures around the Knee, Fracture Management Joint by Joint. Cham, Switzerland: Springer International; 2016:129-149

45 Pallante AL, Chen AC, Ball ST, et al. The in vivo performance of osteochondral allografts in the goat is diminished with extended storage and decreased cartilage cellularity. Am J Sports Med 2012;40(08):1814-1823

46 Pallante AL, Görtz S, Chen AC, et al. Treatment of articular cartilage defects in the goat with frozen versus fresh osteochondral allografts: effects on cartilage stiffness, zonal composition, and structure at six months. J Bone Joint Surg Am 2012;94(21): 1984-1995

47 Williams RJ III, Dreese JC, Chen CT. Chondrocyte survival and material properties of hypothermically stored cartilage: an evaluation of tissue used for osteochondral allograft transplantation. Am J Sports Med 2004;32(01):132-139 
48 Ball ST, Amiel D, Williams SK, et al. The effects of storage on fresh human osteochondral allografts. Clin Orthop Relat Res 2004; (418):246-252

49 Gole MD, Poulsen D, Marzo JM, Ko SH, Ziv I. Chondrocyte viability in press-fit cryopreserved osteochondral allografts. J Orthop Res 2004;22(04):781-787

50 Schachar NS, Novak K, Hurtig M, et al. Transplantation of cryopreserved osteochondral Dowel allografts for repair of focal articular defects in an ovine model. J Orthop Res 1999;17(06):909-919

51 Enneking WF, Campanacci DA. Retrieved human allografts: a clinicopathological study. J Bone Joint Surg Am 2001;83-A(07): 971-986

52 Judas F, Rosa S, Teixeira L, Lopes C, Ferreira Mendes A. Chondrocyte viability in fresh and frozen large human osteochondral allografts: effect of cryoprotective agents. Transplant Proc 2007; 39(08):2531-2534

53 Czitrom AA, Keating S, Gross AE. The viability of articular cartilage in fresh osteochondral allografts after clinical transplantation. J Bone Joint Surg Am 1990;72(04):574-581

54 Williams SK, Amiel D, Ball ST, et al. Prolonged storage effects on the articular cartilage of fresh human osteochondral allografts. J Bone Joint Surg Am 2003;85-A(11):2111-2120

55 Pallante AL, Bae WC, Chen AC, Görtz S, Bugbee WD, Sah RL. Chondrocyte viability is higher after prolonged storage at 37 degrees $C$ than at 4 degrees $C$ for osteochondral grafts. Am J Sports Med 2009;37(Suppl 1):24S-32S

56 Garrity JT, Stoker AM, Sims HJ, Cook JL. Improved osteochondral allograft preservation using serum-free media at body temperature. Am J Sports Med 2012;40(11):2542-2548

57 Strauss EJ, Sershon R, Barker JU, Kercher J, Salata M, Verma NN. The basic science and clinical applications of osteochondral allografts. Bull NYU Hosp Jt Dis 2012;70(04):217-223

58 Ranawat AS, Vidal AF, Chen CT, Zelken JA, Turner AS, Williams RJ III. Material properties of fresh cold-stored allografts for osteochondral defects at 1 year. Clin Orthop Relat Res 2008;466(08):1826-1836

59 Oakeshott RD, Farine I, Pritzker KP, Langer F, Gross AE. A clinical and histologic analysis of failed fresh osteochondral allografts. Clin Orthop Relat Res 1988;(233):283-294

60 Kandel RA, Gross AE, Ganel A, McDermott AG, Langer F, Pritzker KP. Histopathology of failed osteoarticular shell allografts. Clin Orthop Relat Res 1985;(197):103-110

61 Langer F, Gross AE. Immunogenicity of allograft articular cartilage. J Bone Joint Surg Am 1974;56(02):297-304

62 Mandelbaum B, Gortz S, Bugbee WD. Osteochondral allograft transplantation. In: Berry DJ, Azar FM, Lieberman JR, eds. Advanced Reconstruction Knee. Rosemont, IL: American Academy of Orthopaedic Surgeon; 2011:503-510

63 Farr J, Gomoll AH. Osteochondral allograft. In: Farr J, Gomoll AH, eds. Cartilage Restoration. New York, NY: Springer; 2014:1-141

64 Pylawka TK, Wimmer M, Cole BJ, Virdi AS, Williams JM. Impaction affects cell viability in osteochondral tissues during transplantation. J Knee Surg 2007;20(02):105-110

65 Burnett RS, Berger RA, Paprosky WG, Della Valle CJ, Jacobs JJ, Rosenberg AG. Extensor mechanism allograft reconstruction after total knee arthroplasty. A comparison of two techniques. J Bone Joint Surg Am 2004;86-A(12):2694-2699

66 Nazarian DG, Booth RE Jr. Extensor mechanism allografts in total knee arthroplasty. Clin Orthop Relat Res 1999;(367):123-129

67 Rue JP, Yanke AB, Busam ML, McNickle AG, Cole BJ. Prospective evaluation of concurrent meniscus transplantation and articular cartilage repair: minimum 2-year follow-up. Am J Sports Med 2008;36(09):1770-1778

68 Harris JD, Hussey K, Wilson $\mathrm{H}$, et al. Biological knee reconstruction for combined malalignment, meniscal deficiency, and articular cartilage disease. Arthroscopy 2015;31(02):275-282

69 Drexler M, Gross A, Dwyer T, et al. Distal femoral varus osteotomy combined with tibial plateau fresh osteochondral allograft for post-traumatic osteoarthritis of the knee. Knee Surg Sports Traumatol Arthrosc 2015;23(05):1317-1323

70 Shasha N, Krywulak S, Backstein D, Pressman A, Gross AE. Longterm follow-up of fresh tibial osteochondral allografts for failed tibial plateau fractures. J Bone Joint Surg Am 2003;85-A (Suppl 2):33-39

71 Jamali AA, Emmerson BC, Chung C, Convery FR, Bugbee WD. Fresh osteochondral allografts: results in the patellofemoral joint. Clin Orthop Relat Res 2005;(437):176-185

72 Noyes FR, Barber-Westin SD, Rankin M. Meniscal transplantation in symptomatic patients less than fifty years old. J Bone Joint Surg Am 2004;86-A(07):1392-1404

73 Lattermann C, Romine SE. Osteochondral allografts: state of the art. Clin Sports Med 2009;28(02):285-301

74 Krych AJ, Pareek A, King AH, Johnson NR, Stuart MJ, Williams RJ III. Return to sport after the surgical management of articular cartilage lesions in the knee: a meta-analysis. Knee Surg Sports Traumatol Arthrosc 2017;25(10):3186-3196

75 Tírico LEP, McCauley JC, Pulido PA, Bugbee WD. Lesion size does not predict outcomes in fresh osteochondral allograft transplantation. Am J Sports Med 2018. Doi: 10.1177/0363546517746106

76 Giannini S, Buda R, Ruffilli A, et al. Failures in bipolar fresh osteochondral allograft for the treatment of end-stage knee osteoarthritis. Knee Surg Sports Traumatol Arthrosc 2015;23 (07):2081-2089

77 Zou S, Dodd RY, Stramer SL, Strong DM; Tissue Safety Study Group. Probability of viremia with HBV, HCV, HIV, and HTLV among tissue donors in the United States. N Engl J Med 2004;351 (08):751-759

78 Buck BE, Malinin TI, Brown MD. Bone transplantation and human immunodeficiency virus. An estimate of risk of acquired immunodeficiency syndrome (AIDS). Clin Orthop Relat Res 1989; (240):129-136

79 Tomford WW. Transmission of disease through transplantation of musculoskeletal allografts. J Bone Joint Surg Am 1995;77(11): $1742-1754$

80 Simonds RJ, Holmberg SD, Hurwitz RL, et al. Transmission of human immunodeficiency virus type 1 from a seronegative organ and tissue donor. N Engl J Med 1992;326(11): 726-732

81 Davidson PA, Rivenburgh DW, Dawson PE, Rozin R. Clinical, histologic, and radiographic outcomes of distal femoral resurfacing with hypothermically stored osteoarticular allografts. Am J Sports Med 2007;35(07):1082-1090

82 Nielsen ES, McCauley JC, Pulido PA, Bugbee WD. Return to sport and recreational activity after osteochondral allograft transplantation in the knee. Am J Sports Med 2017;45(07): 1608-1614

83 McCarthy MA, Meyer MA, Weber AE, et al. Can competitive athletes return to high-level play after osteochondral allograft transplantation of the knee? Arthroscopy 2017;33(09): $1712-1717$

84 Emmerson BC, Görtz S, Jamali AA, Chung C, Amiel D, Bugbee WD. Fresh osteochondral allografting in the treatment of osteochondritis dissecans of the femoral condyle. Am J Sports Med 2007;35 (06):907-914

85 Gracitelli GC, Tírico LE, McCauley JC, Pulido PA, Bugbee WD. Fresh osteochondral allograft transplantation for fractures of the knee. Cartilage 2017;8(02):155-161

86 Wang D, Kalia V, Eliasberg CD, et al. Osteochondral allograft transplantation of the knee in patients aged 40 years and older. Am J Sports Med 2017. Doi: 10.1177/0363546517741465

87 Frank RM, Lee S, Cotter EJ, Hannon CP, Leroux T, Cole BJ. Outcomes of osteochondral allograft transplantation with and without concomitant meniscus allograft transplantation: a comparative matched group analysis. Am J Sports Med 2018. Doi: $10.1177 / 0363546517744202$ 
88 Colangeli M, Donati D, Benedetti MG, et al. Total knee replacement versus osteochondral allograft in proximal tibia bone tumours. Int Orthop 2007;31(06):823-829

89 Muscolo DL, Ayerza MA, Farfalli G, Aponte-Tinao LA. Proximal tibia osteoarticular allografts in tumor limb salvage surgery. Clin Orthop Relat Res 2010;468(05):1396-1404

90 Hornicek FJ Jr, Mnaymneh W, Lackman RD, Exner GU, Malinin TI. Limb salvage with osteoarticular allografts after resection of proximal tibia bone tumors. Clin Orthop Relat Res 1998;(352):179-186

91 Shi X, Wu S, Zhao J. Limb salvage with osteoarticular allografts after resection of proximal tibia bone [in Chinese].Zhongguo Xiu Fu Chong Jian Wai Ke Za Zhi 2006;20(10):966-969

92 Imanishi J, Grinsell D, Choong PF. Bone-patellar tendon-bone allograft reconstruction for peri-patellar tendon sarcomas: case series. Springerplus 2015;4:740

93 Drexler M, Blumberg N, Haim A, Arbel R, Morag G. Extensor mechanism reconstruction: a novel technique for bone patella allograft post partial patellectomy failure. J Knee Surg 2011;24 (02):129-135

94 Rosenberg AG. Management of extensor mechanism rupture after TKA. J Bone Joint Surg Br 2012;94(11, Suppl A):116-119
95 Malhotra R, Garg B, Logani V, Bhan S. Management of extensor mechanism deficit as a consequence of patellar tendon loss in total knee arthroplasty: a new surgical technique. J Arthroplasty 2008;23(08):1146-1151

96 Springer BD, Della Valle CJ. Extensor mechanism allograft reconstruction after total knee arthroplasty. J Arthroplasty 2008;23(7, Suppl):35-38

97 Torga Spak R, Teitge RA. Fresh osteochondral allografts for patellofemoral arthritis: long-term followup. Clin Orthop Relat Res 2006;444(444):193-200

98 Lattermann C, Kremser V, Altintas B. Use of fresh osteochondral allografts in the patellofemoral joint. J Knee Surg 2017. Doi: 10.1055/s-0037-1607324

99 Gracitelli GC, Meric G, Pulido PA, Görtz S, De Young AJ, Bugbee WD. Fresh osteochondral allograft transplantation for isolated patellar cartilage injury. Am J Sports Med 2015;43(04): 879-884

100 Farr J, Gracitelli GC, Shah N, Chang EY, Gomoll AH. High failure rate of a decellularized osteochondral allograft for the treatment of cartilage lesions. Am J Sports Med 2016;44(08): 2015-2022 